\title{
CASE STUDY ON ENHANCED LANDFILL MINING AT MONT-SAINT- GUIBERT LANDFILL IN BELGIUM: CHARACTERIZATION AND POTENTIAL OF FINE FRACTIONS
}

\author{
Juan Carlos Hernández Parrodi 1,3,*, Cristina García López ${ }^{2}$, Bastian Küppers ${ }^{1}$, Karoline \\ Raulf ${ }^{2}$, Daniel Vollprecht ${ }^{1}$, Thomas Pretz ${ }^{2}$ and Roland Pomberger ${ }^{1}$
}

\footnotetext{
${ }^{1}$ Montanuniversität Leoben, Department of Environmental and Energy Process Engineering, 8700 Leoben, Austria

${ }^{2}$ RWTH Aachen University, Department of Processing and Recycling, 52062 Aachen, Germany

${ }^{3}$ Renewi Belgium SA/NV, NEW-MINE project, 3920 Lommel, Belgium
}

Article Info:
Received:
11 June 2019
Revised:
2 August 2019
Accepted:
19 August 2019
Available online:
23 December 2019
Keywords:
Enhanced landfill mining
Waste characterization
Waste to material
Waste to energy
Fine fractions
Fines

Article Info:

11 June 2019

Revised:

19 August 2019

Available online:

Keywords:

Enhanced landfill mining

Waste characterization

Fines

\begin{abstract}
Within the framework of the "EU Training Network for Resource Recovery through Enhanced Landfill Mining - NEW-MINE", around $374 \mathrm{Mg}$ of waste were excavated from a landfill site in Mont-Saint-Guibert, Belgium. Parameters such as bulk density, water content, particle size distribution and material composition of the fine fractions (material $<90 \mathrm{~mm}$ ) were determined and analyzed. The present investigation has the main objective to document and disseminate the findings on the material characterization of the fine fractions obtained in this case study, since such information is of critical relevance for the design of an effective and efficient mechanical processing in (enhanced) landfill mining projects. Additionally, the potential of the fine fractions for material and energy recovery is discussed. The fine fractions in question were obtained through the implementation of a ballistic separation process with simultaneous screening directly after excavation, from which about $77 \mathrm{wt} . \%$ of the total amount of processed material in raw state corresponded to the fine fractions. These fractions presented an overall bulk density range of $720-1000 \mathrm{~kg} / \mathrm{m}^{3}$ in raw state and a total water content range of $25-30 \mathrm{wt} . \%$. In dry state, the material showed a more uniform particle size distribution than in raw state, and results confirm that water content has a large impact on the particle size distribution of the fine fractions, as well as on the content of impurities in the material fractions "Combustibles", "Inert", "Total metals" and "Others" and on the presence of agglomerates. Results on the material composition in dry state reveal that amounts of 2.1-19.7 wt.\% "Combustibles", 31.1-35.4 wt.\% "Inert" and 0.6-1.8 wt.\% "Total metals" could be recovered from the fine fractions $90-10 \mathrm{~mm}$, while $37.8-55.6 \mathrm{wt} . \%$ "Fine fractions $<10 \mathrm{~mm}$ " could be processed further in order to increase the recovery amounts of the previous material fractions and produce a substitute material for soil in construction applications.
\end{abstract}

\section{INTRODUCTION}

In general terms, (enhanced) landfill mining ((E)LFM) aims for the mitigation of pollution originating from landfill sites, reduction of aftercare and closure costs, land reclamation in urban areas, material recovery and, among many others, regaining landfill capacity (Hernández Parrodi et al., 2019; Hull et al., 2005; Jones et al., 2013; Jones et al., 2010; Jones and Tielemans, 2010; Krook et al., 2012). Particularly, the recovery of materials from the excavated material for recycling and production of alternative fuels has been included into the scope of many recent investigations in an attempt to raise the overall economic feasibility of (E) LFM projects (Hernández Parrodi et al., 2018a, 2018b).
Nevertheless, mainly the coarse fractions (material with a particle size $\geq 10 \mathrm{~mm}$ to $\geq 60 \mathrm{~mm}$, depending on the investigation) have been used for waste-to-material (WtM) and waste-to-energy (WtE) purposes in those investigations.

Concurrently, it has been identified in previous research that fine fractions (material with a particle size $<60 \mathrm{~mm}$ to $<10 \mathrm{~mm}$, depending on the investigation), which represent about $40-80$ wt. \% of the total amount of excavated material, can be a relevant source for material and energy recovery (Hernández Parrodi et al., 2018a, 2018b). These fractions have been re-directed to the landfill, to a large extent, with poor or without any treatment at all (Bhatnagar et al., 2017; Münnich et al., 2013) and, therefore, the exploitation of their potential is of utmost relevance to increase the overall 
material and energy recovery in (E)LFM projects.

In order to assess the potential for material and energy recovery from the fine fractions of a particular landfill site, it is necessary to determine their material composition and main characteristics, such as bulk density, water content and particle size distribution (PSD). The present study has the main aim to document and disseminate the findings of the material characterization obtained through this investigation, as well as to discuss the potential of the examined fine fractions for WtM and WtE.

\section{MATERIALS AND METHODS \\ 2.1 Site description}

The investigated landfill site in this case study is the "Centre d'enfouissement Technique de Mont-Saint-Guibert (CETeM)" located in the municipality of Mont-Saint-Guibert (MSG), Belgium (Figure 1a). Founded on a former sand quarry, which was exploited from 1937 to 1985, this landfill has served as one of the main disposal sites of municipal solid waste (MSW), non-hazardous industrial waste (IW) and construction \& demolition waste (C\&D) to the Belgian province of Walloon Brabant from 1958 (Bureau d'études greisch, 2002) to 2014. Nowadays, this site is going through its closure process, which is expected to conclude by the end of 2020 .

MSG landfill has a total area of around 44.3 ha ( $D^{\prime} O r$, 2013), which is delimited in yellow in Figure 1b. The total area is divided into two main parts, namely the modern part and the old part of the site. The modern part has an area of about 26.5 ha (IGRETEC, 1994), which is delimited in blue in Figure $1 \mathrm{~b}$, while an estimated area of 14 ha corresponds to the old part, which is delimited in red in Figure $1 \mathrm{~b}$.

The present investigation was carried out at the old part of the landfill, which has an estimated depth between $30 \mathrm{~m}$ and $60 \mathrm{~m}$ and where at least 5.7 million $\mathrm{m}^{3}$ of waste were disposed of between 1958 and 1985 (Gaël et al., 2017; IGRETEC, 1994). The old part of the landfill had a biogas collection system of vertical wells during the 1980s, which was removed after the stabilization of the waste, and has a functioning leachate collection system that consists of a lateral drain still in place.

Multi-sensor geophysical data from the subsurface of the old landfill's body were gathered from three different areas during July-August 2017, from which one of them was selected for further geophysical exploration. Some decisive criteria for the selection of the exploration area were lateral and vertical extents, as well as the largest possible
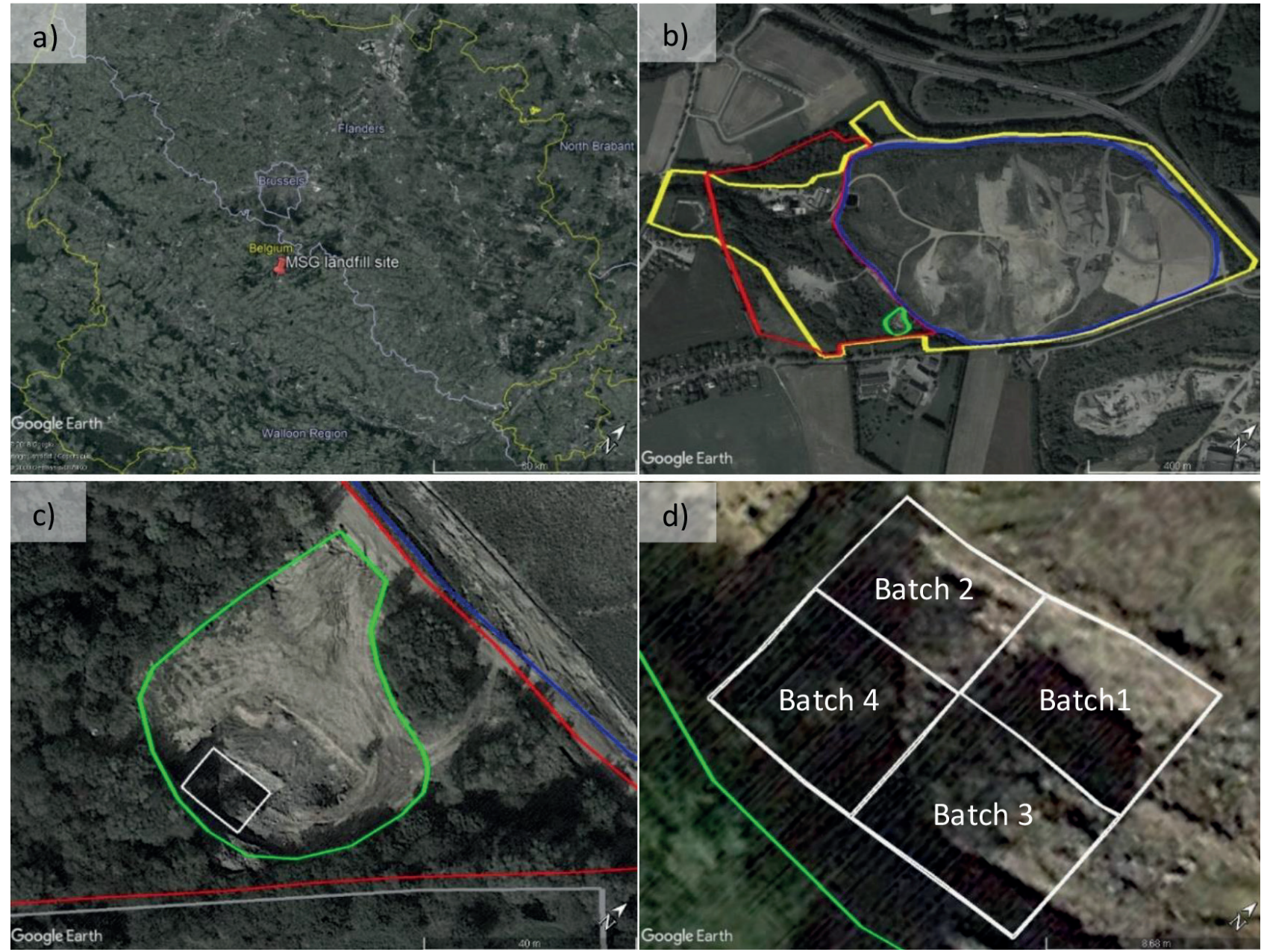

FIGURE 1: a) Location of landfill site in Belgium, b) MSG landfill site, c) exploration area and excavation zone and d) excavation zone with batches. 
range of apparent surface electrical conductivity. The selected geophysical exploration area was around $2150 \mathrm{~m}^{2}$, which is delimited in green in Figure 1b,c. Based on the results of the geophysical measurements, an excavation zone was selected within the selected exploration area due to its potential to validate measured geophysical properties of various unknown materials, since it was assumed a priori that a large variation range in electrical conductivity would coincide with a large variation in type of materials. The selected excavation zone had an area of about $130 \mathrm{~m}^{2}$ and is delimited in white in Figure 1c. This zone is shown in greater detail in Figure $1 \mathrm{~d}$ as well.

The concessioner for the operation of the landfill site is the company Renewi Belgium SA/NV, which has operated the site for over 25 years and provided most of the necessary equipment and manpower to realize this study.

\subsection{Excavation works and material pre-processing}

The material excavation and mechanical pre-processing were carried out during the last week of August and first week of September, 2017. The total excavated volume was divided into four sub-volumes, which are henceforth referred to as batches in this study (Figure 1d). The excavated volume was about $10 \mathrm{~m}$ long, $10 \mathrm{~m}$ wide and $4 \mathrm{~m}$ deep, while batches were around $5 \mathrm{~m}$ long and $5 \mathrm{~m}$ wide and had varying depths. The batches were classified in-situ according to their composition, since a clear waste stratification was identified visually within the excavated volume. As shown in Figure $2 b$, the first $2 \mathrm{~m}$ of the excavated volume consisted of a layer of mainly C\&D, whereas below this layer the material corresponded to a layer of about $2 \mathrm{~m}$ of mostly MSW with daily cover layers of clay in between. Batch 1 and batch 2 were both excavated completely and, therefore, they were mainly composed of a mixture of MSW and C\&D. For batch 3 and batch 4 the layers of C\&D (upper layer) and MSW (bottom layer) were excavated individually in such a way that they predominantly consisted of C\&D and MSW, respectively. Batches 1 to 4 were handled separately with the main purpose of studying their characteristics and mechanical processability as a mixture of C\&D and MSW (batch 1 and batch 2) and as mostly C\&D (batch 3) and MSW (batch 4), which allowed to obtain a more detailed insight into the performance of the mechanical processing with significant variations in the input material.

For the extraction of the waste material from the landfill, Hitachi 250LC and Liebherr 934 excavators with toothed digging type buckets of $2.5 \mathrm{~m}^{3}$ were employed, while for the manipulation of the excavated material a Caterpillar $972 \mathrm{~K}$ wheel loader equipped with a $3.5 \mathrm{~m}^{3}$ bucket was utilized
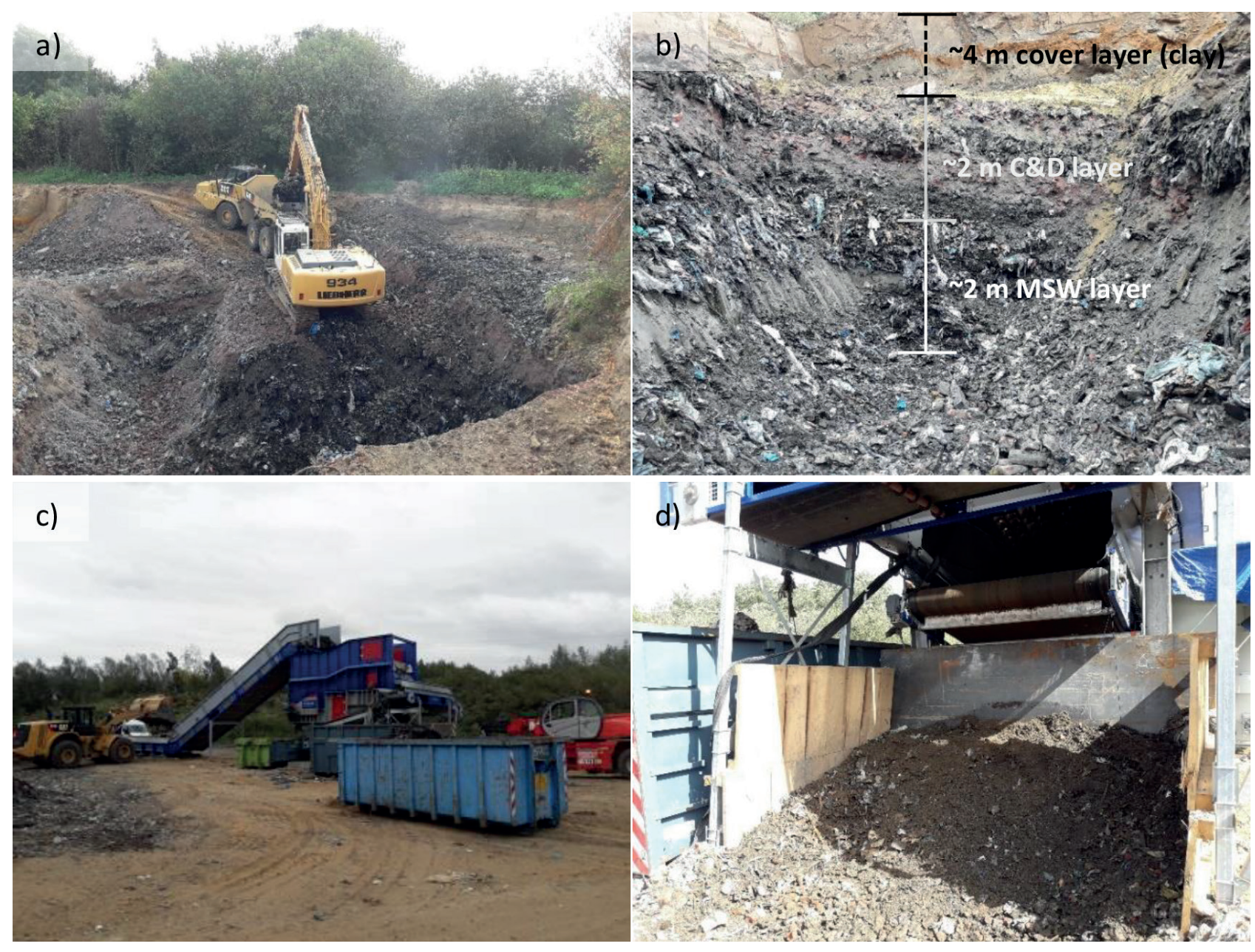

FIGURE 2: a) Material excavation, b) excavation volume, c) ballistic separator and d) fine fractions. 
(Figure 2a,c). During the excavation works the cover layer was removed first, which was mainly composed of clay and had an estimated average thickness of about $4 \mathrm{~m}$ (Figure $2 b$ ), in order to keep it separated from the landfilled waste. The cover layer material was not further processed. Subsequently, the excavated material was transported with Caterpillar $730 \mathrm{C}$ articulated trucks of $13.9 \mathrm{~m}^{3}$ (each) from the excavation zone to the mechanical pre-processing area (Figure 2a,c). The weight of the excavated material was determined with a weighing bridge of $50 \mathrm{Mg}$ capacity and a resolution of $50 \mathrm{~kg}$.

The fine fractions were obtained through the implementation of a two-step ballistic separation process (Figure $2 \mathrm{~d}$ ) with simultaneous screening (screening paddles). The ballistic separator (Stadler model STT 6000) sorted the input material into three-dimensional (3D), two-dimensional (2D) and under-screen fractions according to density, shape and particle size differences. In the ballistic separation process the screening paddles were firstly set to sieve the input material at $200 \mathrm{~mm}$ and subsequently at $90 \mathrm{~mm}$. In this case study the fine fractions were defined as the excavated landfill material with a particle size $<90 \mathrm{~mm}$ obtained from the second processing step of the ballistic separator. Figure 3 provides a schematic overview of the ballistic separation process, as well as of the outputs from which samples were taken. Additional details about the ballistic separator and the mechanical pre-processing and processing of the coarse fractions ( $\geq 90 \mathrm{~mm}$ ) can be found in García López et al., 2019.

After being pre-processed with the ballistic separator, the fine fractions were loaded into containers of $25 \mathrm{~m}^{3}$ with a Manitou MRT 2150 telescopic handler equipped with a $2.5 \mathrm{~m}^{3}$ bucket to be stored until further processing.

\subsection{Material samples and laboratory analysis}

Due to the large amount of material excavated and pre-processed, representative single samples of the output fractions of the ballistic separator were taken for further analysis (Figure 4a). In this way, the quantity of material to be characterized and the amount of laboratory analysis can be reduced without compromising the reliability of the results. For this, the German guideline for procedures for physical, chemical and biological testing in connection with the recovery/disposal of waste (LAGA PN 98) was followed, which specifies the amount and size of the samples to be taken, according to the type, amount and particle size of the material to be sampled.

The sampling of the obtained fine fractions was done directly at the output chute of the ballistic separator. Two single samples of $10 \mathrm{I}$ (each) were taken every 7.5 minutes in order to accumulate an amount of sixteen single samples per batch of processed material in $1 \mathrm{~h}$. Eight composite samples (Figure 4c) of $20 \mathrm{I}$ (each) were prepared on-site from every set of sixteen single samples, using the quartering method, as shown in Figure 4b.

The composite samples were used to determine the material composition and physical properties of the fine fractions at the raw materials laboratory and technical facility of the Department of Processing and Recycling (IAR) of the RWTH Aachen University. The material characterization was done in dry and raw states in order to allow direct comparison of the results. A circular vibratory box

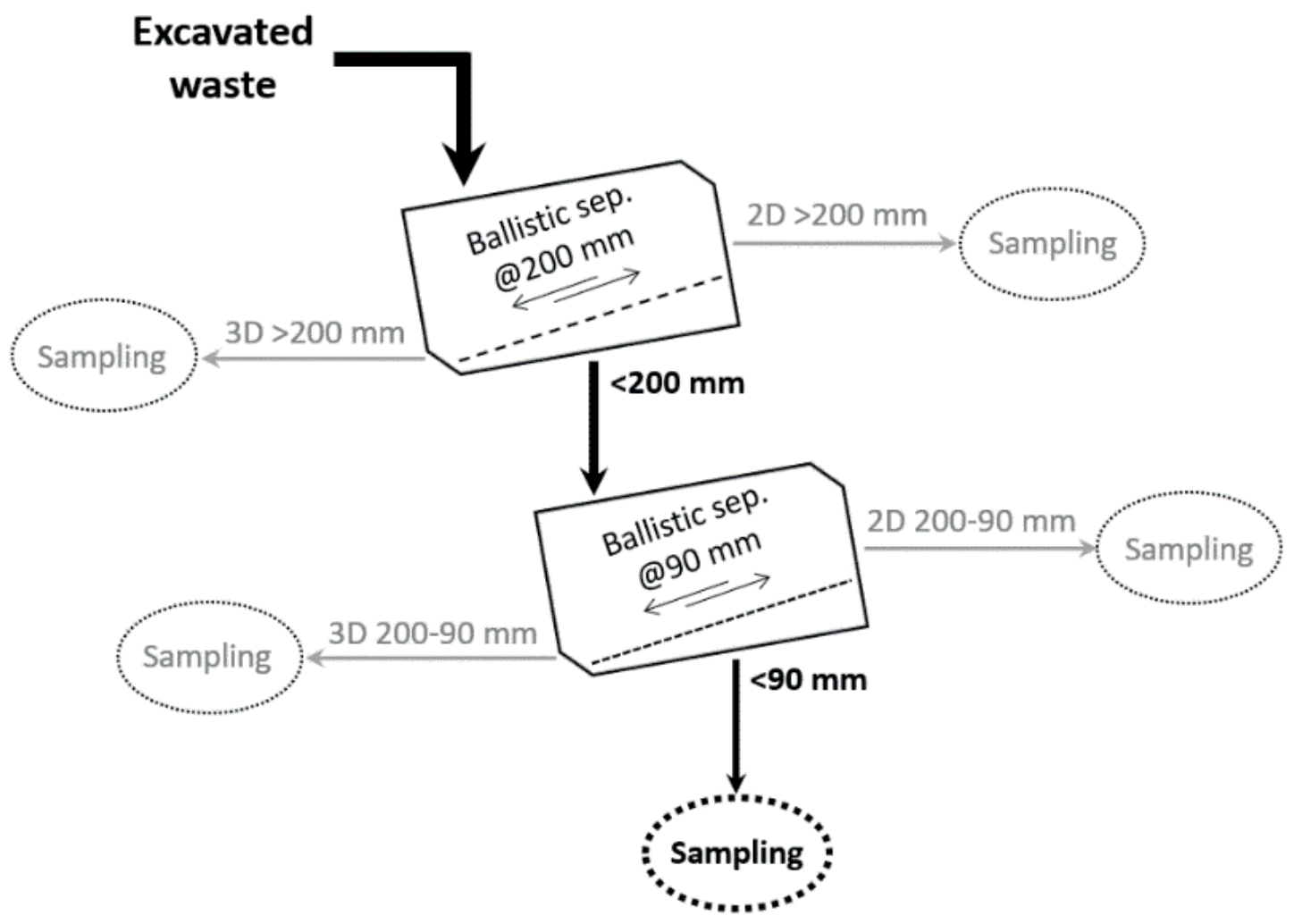

FIGURE 3: Pre-processing of excavated waste with ballistic separator. 

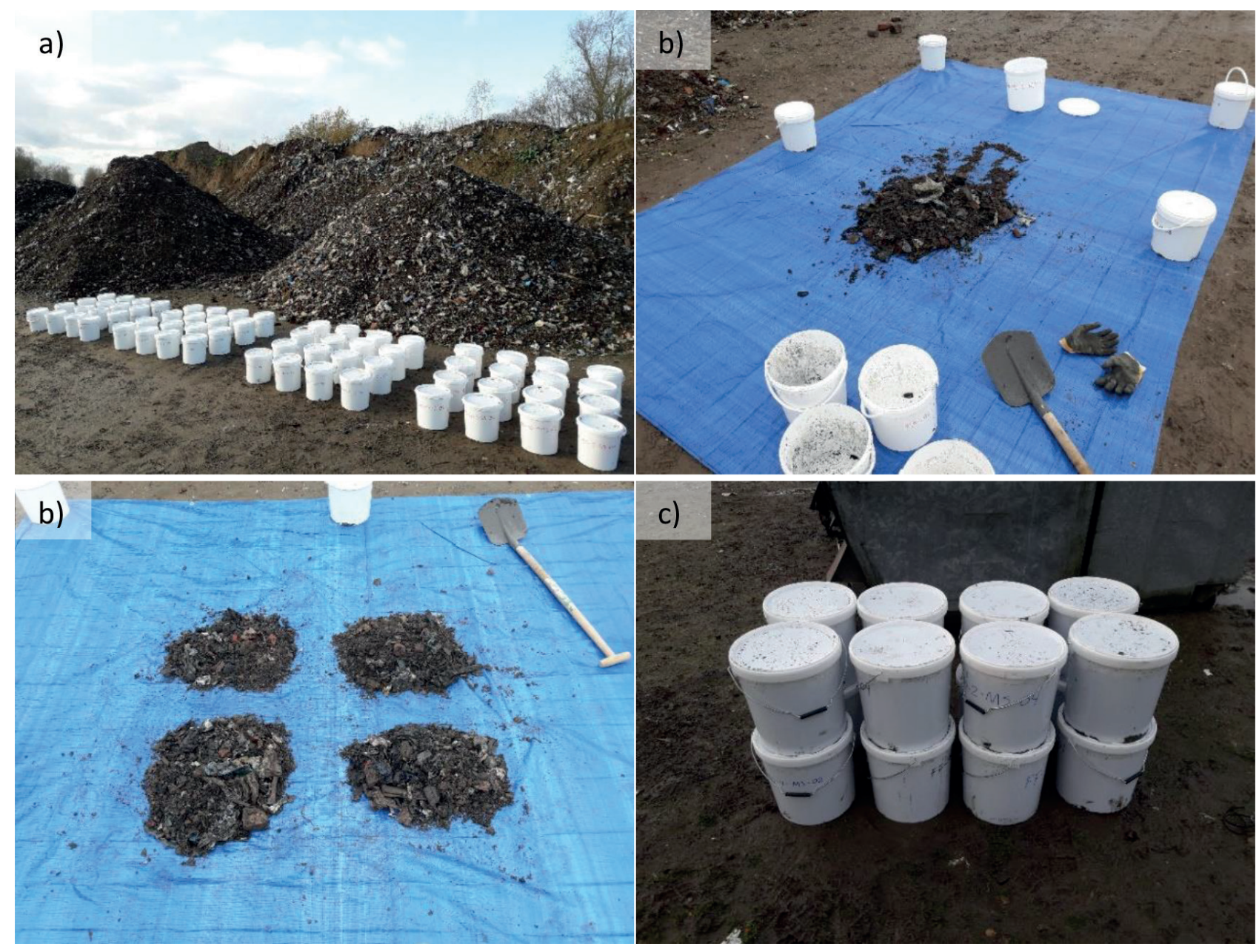

FIGURE 4: a) Single samples, b) quartering method and c) composite samples.

sieve (Siebtechnik, $500 \mathrm{~mm} \times 500 \mathrm{~mm}$ ) with circular reticle sieves of $63 \mathrm{~mm}, 31.5 \mathrm{~mm}$ and $10 \mathrm{~mm}$ and a circular vibratory sieve tower (Siebtechnik, $\varnothing 400 \mathrm{~mm}$ ) with squared reticle sieves of $6.3 \mathrm{~mm}, 3.15 \mathrm{~mm}, 1.0 \mathrm{~mm}, 0.63 \mathrm{~mm}, 0.315$ $\mathrm{mm}$ and $0.16 \mathrm{~mm}$ were used to determine the PSD, which was performed according to the norm DIN EN 154151:2011. Water and dry mass contents were determined according to the norm DIN EN 14346 (modified: drying at $75^{\circ} \mathrm{C} \pm 5^{\circ} \mathrm{C}$ to prevent loss of volatile matter and melting of certain plastics). The drying of the samples was done in a Heraeus industrial drying oven. For the determination of the bulk density, the norm DIN SPEC CEN/TS 15401:2010 was followed. An industrial platform scale (Kern DS 150K1, resolution of $1.0 \mathrm{~g}$ ) and a precision balance (Kern KB 2400$2 \mathrm{~N}$, resolution of $0.01 \mathrm{~g}$ ) were used to determine the corresponding weights of all samples.

For the determination of the material composition, manual sorting was performed to particle size ranges $\geq 10$ $\mathrm{mm}$ following the procedure described by the German guideline for uniform waste analysis in Saxony (Richtlinie zur einheitlichen Abfallanalytik in Sachsen). Grouped material fractions, such as "Combustibles" (i.e. "3D plastics", "2D plastics", "Textiles", "Wood", "Leather" and "Paper, Paperboard and Cardboard (PPC)"), "Inert" (i.e. "Bricks/ Concrete/Stones", "Ceramics" and "Glass"), "Total metals" (i.e. "Fe metals" and "Non-Fe metals"), "Others" (i.e. bones, shells, sponges and unidentifiable materials), "Agglomerated fines $<10 \mathrm{~mm}$ " (i.e. material $<10 \mathrm{~mm}$ that stuck together due to the presence of moisture and formed material agglomerates) and "Fine fractions $<10 \mathrm{~mm}$ " (i.e. soil, organic and weathered inert materials) were employed for the classification of the material composition.

\section{RESULTS AND DISCUSSION}

A total amount of about $374 \mathrm{Mg}$ of waste was excavated and pre-processed at the MSG landfill, from which around $77 \mathrm{wt} . \%$ (raw state) corresponded to the fine fractions. The excavated pit (Figure 1d) had a total volume of about $425 \mathrm{~m}^{3}$. As described in Section 2.2, the excavated volume was divided into four batches, which were about $140 \mathrm{~m}^{3}$ (batch 1), $100 \mathrm{~m}^{3}$ (batch 2), $120 \mathrm{~m}^{3}$ (batch 3) and $65 \mathrm{~m}^{3}$ (batch 4). Batch 1 and batch 2 consisted mainly of a mixture of MSW and C\&D (Figure 5a,b), while batch 3 (Figure $5 c$ ) and batch 4 (Figure $5 \mathrm{~d}$ ) were mostly composed of C\&D and MSW, respectively.

The total weights of the excavated batches in raw state were about $111 \mathrm{Mg}$ for batch 1, $59 \mathrm{Mg}$ for batch 2, 149 $\mathrm{Mg}$ for batch 3 and $55 \mathrm{Mg}$ for batch 4, from which about 80 wt. $\%, 76$ wt. $\%, 73$ wt. $\%$ and 80 wt.\% corresponded to 

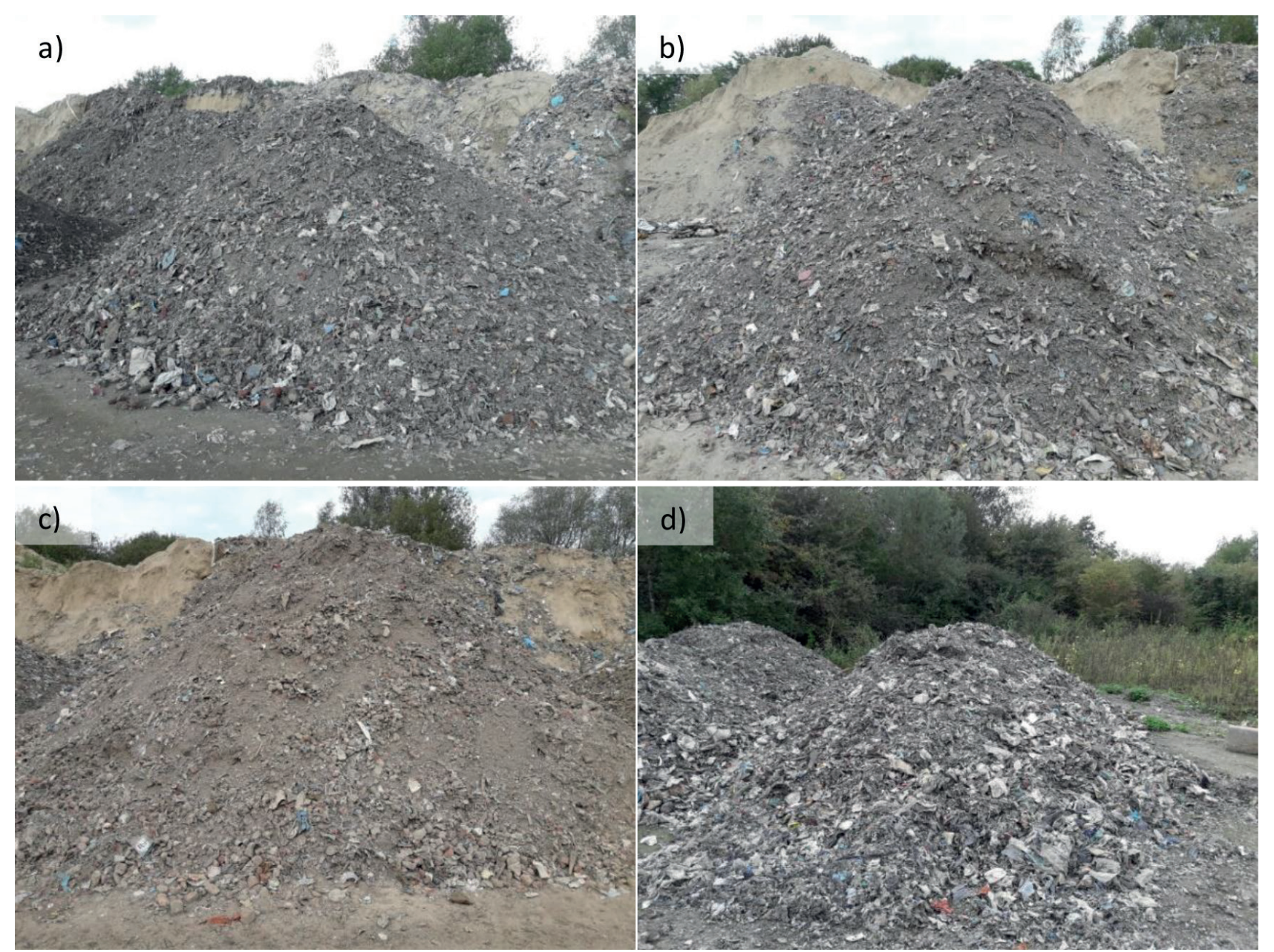

FIGURE 5: Fine fractions in raw state - a) batch 1, b) batch 2, c) batch 3 and d) batch 4 .

the fine fractions, respectively. Table 1 summarizes the amounts and characteristics of the fine fractions obtained of each batch from the mechanical pre-processing.

The total mass and volume of the excavated material, as well as of the obtained fine fractions were determined by means of the articulated trucks and weighing bridge. Bulk density, water content, PSD and material composition were determined from the analysis of composite samples at IAR's technical facility.

\subsection{Bulk density and water content}

Bulk density and water content are key parameters for the design of an effective and efficient mechanical processing of fine fractions, since the type of process- ing methods (i.e. processing approach) and size/number of processing units to be employed depend on them to a great extent. Hence, both bulk density and water content belong to the foremost parameters to be determined from fine fractions in (E)LFM. To this end, an amount of eight composite samples $(n=8)$ was used to determine the bulk density in the raw state of each batch. The results were used to calculate different percentiles, as percentiles are a useful measure to identify the variation range in a set of values, while excluding a certain percentage of them that are less likely to occur according to pre-selected low and high limits. The 25th, 50th (median) and 75th percentiles were found to be the most useful for depicting the fluctuations of the bulk density. These results, together with the

TABLE 1: Amounts of excavated waste and fine fractions in raw state.

\begin{tabular}{|c|c|c|c|c|}
\hline Batch & Material type & $\begin{array}{l}\text { Amount of excavated } \\
\text { waste [Mg] }\end{array}$ & $\begin{array}{c}\text { Volume of excavated } \\
\text { waste }\left[\mathrm{m}^{3}\right]\end{array}$ & $\begin{array}{l}\text { Amount of fine fractions from } \\
\text { excavated waste [wt. \%] }\end{array}$ \\
\hline 1 & $M S W+C \& D$ & 111 & 140 & 80 \\
\hline 2 & MSW + C\&D & 59 & 100 & 76 \\
\hline 3 & Mostly C\&D & 149 & 120 & 73 \\
\hline 4 & Mostly MSW & 55 & 65 & 80 \\
\hline & Total & 374 & 425 & 77 \\
\hline
\end{tabular}


maximum and minimum values, are shown as box-andwhisker plots in Figure 6a.

Results show that the bulk densities of batches 1 and 2 were quite similar, while those of batches 3 and 4 were very different from each other. Batch 3 presented a median bulk density around $1230 \mathrm{~kg} / \mathrm{m}^{3}$, which is comparable to that of $C \& D$, with a very narrow variation between 25 th and 75 th percentiles accounting for the homogeneity of the material. Batch 4 had a median bulk density of about $630 \mathrm{~kg} /$ $\mathrm{m}^{3}$, which corresponds to that of MSW, with a wider variation between 25th and 75th percentiles accounting for the heterogeneous nature of MSW. The determined bulk densities of batches 1 and 2 were located in between those of batches 3 and 4 with medians around $850 \mathrm{~kg} / \mathrm{m}^{3}$ (batch 1) and $810 \mathrm{~kg} / \mathrm{m}^{3}$ (batch 2) and a stronger overall variation between 25th and 75th percentiles, which logically correlates to a mixture of both C\&D and MSW. In general, the bulk density of the fine fractions (all batches) varied between 720 $\mathrm{kg} / \mathrm{m}^{3}$ and $1000 \mathrm{~kg} / \mathrm{m}^{3}$ with a median of about $810 \mathrm{~kg} / \mathrm{m}^{3}$.

Regarding water content, four composite samples $(n=4)$ were used to determine the moisture content of each batch, since the remaining amount of composite samples were used to determine the material composition in raw state. Analogously to bulk density, the 25th, 50th and 75th percentiles, and the maximum and minimum values of the water content were used to plot the corresponding box-and-whisker diagrams, which are displayed in Figure 6b.

Batches 1 and 2 showed very similar results with regard to water content, both with medians of about $27 \mathrm{wt} . \%$ and very slight variations between 25 th and 75 th percentiles. On the contrary, batches 3 and 4 presented water content medians of around $18 \mathrm{wt} . \%$ and $37 \mathrm{wt} . \%$, respectively, with relatively larger variations between 25 th and 75 th percentiles. Altogether, the water content of the fine fractions had a median of about $27 \mathrm{wt} . \%$ and fluctuated between $25 \mathrm{wt} . \%$ and $30 \mathrm{wt} . \%$. Thus, an overall bulk density range of $720-$ $1000 \mathrm{~kg} / \mathrm{m}^{3}$ and a total water content range of 25-30 wt.\% can be used to describe the fine fractions of MSG landfill.

Additionally, four $(n=4)$ and eight $(n=8)$ composite samples were used to determine the variation of bulk density with particle size in raw and dry states, respectively. This information is plotted in Figure 7, in which it can be observed that bulk density had slight variations between particle sizes of $1 \mathrm{~mm}$ and $6 \mathrm{~mm}$, but strong ones between $6 \mathrm{~mm}$ and $90 \mathrm{~mm}$ in both states. The curves for raw state (shown in blue in Figure 7) begin at $1 \mathrm{~mm}$ because in this state particle sizes mostly $<1 \mathrm{~mm}$ tend to adhere to each other and form agglomerates with diameters above $1 \mathrm{~mm}$. From these results it can be said that, practically, bulk density decreased as particle size increased for both raw and dry states. Nonetheless, a decrease in bulk density was observed below $0.16 \mathrm{~mm}$ in dry state, probably because most of the remaining materials with high densities, such as ceramics, stones, glass and metals, were found above that particle size range.

The comparison of the medians of the raw data between raw and dry states, for several particle size ranges, reveals that bulk density decreased about $12 \%$ in the particle size range between $90-63 \mathrm{~mm}, 30 \%$ in $63-31.5 \mathrm{~mm}, 33 \%$ in $31.5-10 \mathrm{~mm}, 21 \%$ in $10-6.3 \mathrm{~mm}, 23 \%$ in $6.3-3.15 \mathrm{~mm}$ and $16 \%$ in $3.15-1 \mathrm{~mm}$ after drying with respect to raw state. The overall median of the reduction in bulk density of the fine fractions after drying was around $21 \%$, which can be very useful information for the design of the mechanical processing.

Furthermore, four composite samples $(n=4)$ from each of the batches 1,3 and 4 after manual characterization were used to determine the water content per type of material, for three particle size ranges $(90-63 \mathrm{~mm}, 63-31.5 \mathrm{~mm}$
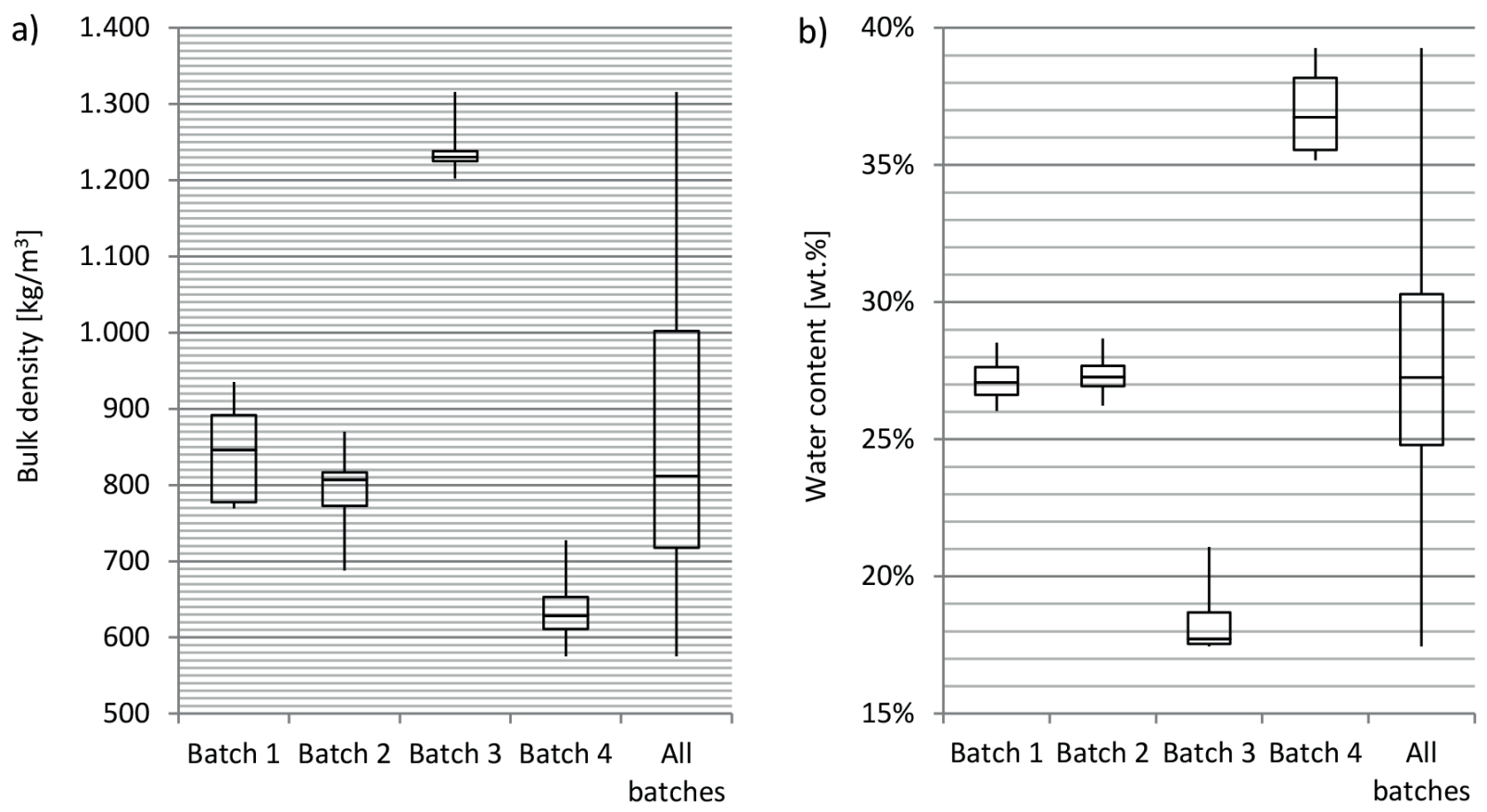

FIGURE 6: a) Bulk density in raw state and b) water content of the fine fractions. 


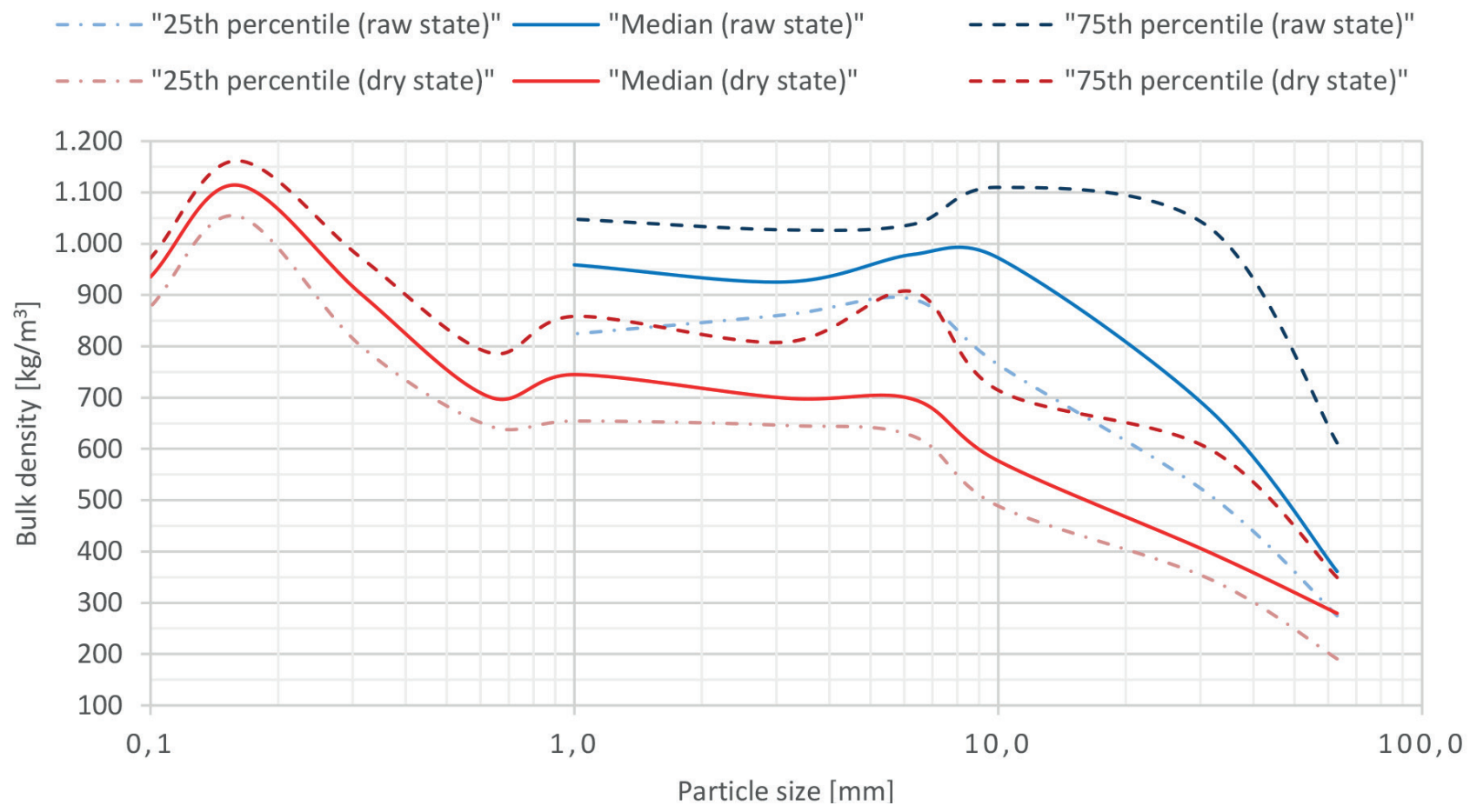

FIGURE 7: Variation of bulk density with particle size in the fine fractions in raw (blue) and dry (red) states.

and $31.5-10 \mathrm{~mm}$ ), in order to study the water distribution among them. This information is shown in Table 2.

The materials presented in Table 2 can be classified into those with high, medium and low water contents. "PPC" and "Wood" showed the highest values, while "Bricks/Concrete/stones", "Ceramics", "Glass", "Fe metals" and "Non-Fe metals" presented the lowest values. Despite being among the materials with the lowest water content, "Ceramics", "Glass", "Fe metals" and "Non-Fe metals" show considerable amounts of water, which can be explained by the presence of impurities. In this case study impurities are regarded as fine particles (mainly $<1 \mathrm{~mm}$ ) of organic and inorganic matter that attach to the surface of coarser particles (also known as surface defilements). Impurities are

TABLE 2: Water content per material type of the fine fractions $90-10 \mathrm{~mm}$.

\begin{tabular}{|c|c|c|c|c|c|c|c|c|c|}
\hline \multirow{3}{*}{$\begin{array}{l}\text { Material } \\
\text { type }\end{array}$} & \multicolumn{9}{|c|}{ Particle size range } \\
\hline & \multicolumn{3}{|c|}{$90-63 \mathrm{~mm}$} & \multicolumn{3}{|c|}{$63-31.5 \mathrm{~mm}$} & \multicolumn{3}{|c|}{$31.5-10 \mathrm{~mm}$} \\
\hline & $\begin{array}{c}25^{\text {th }} \\
\text { percentile }\end{array}$ & Median & $\begin{array}{c}75^{\text {th }} \\
\text { percentile }\end{array}$ & $\begin{array}{c}25^{\text {th }} \\
\text { percentile }\end{array}$ & Median & $\begin{array}{c}75^{\text {th }} \\
\text { percentile }\end{array}$ & $\begin{array}{c}25^{\text {th }} \\
\text { percentile }\end{array}$ & Median & $\begin{array}{c}75^{\text {th }} \\
\text { percentile }\end{array}$ \\
\hline 3D plastics & 16.2 & 19.9 & 25.2 & 20.3 & 22.5 & 27.3 & 18.3 & 20.5 & 24.2 \\
\hline 2D plastics & 18.4 & 26.4 & 34.4 & 25.8 & 31.4 & 33.2 & 24.4 & 27.8 & 32.7 \\
\hline Leather & N.A. & N.A. & N.A. & 11.5 & 20.3 & 29.0 & 8.1 & 12.6 & 16.2 \\
\hline PPC & 55.1 & 60.4 & 63.4 & 54.6 & 57.8 & 59.3 & 45.9 & 50.8 & 53.9 \\
\hline Textiles & 26.9 & 32.9 & 34.6 & 22.3 & 33.7 & 39.1 & 22.6 & 26.3 & 30.6 \\
\hline Wood & 57.8 & 60.1 & 60.7 & 53.1 & 56.1 & 59.7 & 43.7 & 47.2 & 56.0 \\
\hline $\begin{array}{l}\text { Bricks/Concrete/ } \\
\text { Stones }\end{array}$ & 8.4 & 12.3 & 12.6 & 12.7 & 13.5 & 14.2 & 14.4 & 15.4 & 16.4 \\
\hline Ceramics & 4.5 & 5.8 & 7.0 & 3.0 & 4.6 & 6.3 & 2.2 & 6.2 & 13.2 \\
\hline Glass & 0.0 & 0.0 & 0.0 & 0.9 & 2.1 & 3.1 & 3.3 & 3.7 & 5.0 \\
\hline Fe metals & 0.2 & 0.3 & 0.7 & 3.2 & 5.3 & 8.9 & 3.1 & 8.8 & 13.7 \\
\hline $\begin{array}{l}\text { Non-Fe } \\
\text { metals }\end{array}$ & 0.5 & 1.0 & 1.4 & 1.5 & 5.8 & 8.6 & 2.5 & 10.0 & 15.5 \\
\hline Others & 43.9 & 45.9 & 48.0 & 17.8 & 21.5 & 37.3 & 19.8 & 23.7 & 31.0 \\
\hline $\begin{array}{l}\text { Agglomerated } \\
\text { fines }<10 \mathrm{~mm}\end{array}$ & 19.5 & 27.8 & 29.8 & 25.7 & 32.6 & 39.1 & 21.7 & 29.1 & 38.5 \\
\hline
\end{tabular}

Notes: Figures are given in wt.\%. Materials for which no sample was obtained are denoted as not available (N.A.) 
associated with an increase of water content due to their capability to absorb and adsorb water. "3D plastics" and "2D plastics", "Leather", "Textiles", as well as "Others" and "Agglomerated fines $<10 \mathrm{~mm}$ ", belong to the materials with medium water contents. Similarly to "Ceramics", "Glass", "Fe metals" and "Non-Fe metals", the moderate water contents of "3D plastics" and "2D plastics" are most likely to be due to the presence of impurities. This type of information results very useful during the design of the mechanical processing, as the effectivity of density separation methods can be greatly influenced by by the water content.

Moreover, no conclusive trend was identified regarding water content and particle size range, except for "Glass", "Fe metals" and "No-Fe metals", whose water contents increased as the particle size range decreased. The latter can be explained by the fact that the impurities vs. material type mass-ratio increases with the reduction in particle size of the material type.

After sieving in raw state, four composite samples $(n=4)$ from each of the batches 2, 3 and 4 were employed for the determination of the water content per particle size range, which allowed to identify if some tendency of water being retained by a certain particle size range was to be found. This information was correlated with the mass distribution throughout the particle size ranges in question, so that its influence in the water distribution could be studied as well. This correlation is depicted in Figure 8.

Figure 8 shows that the water content was more or less evenly distributed throughout the fine fractions, as well as that most of the material and water were concentrated in the particle size range $31.5-10 \mathrm{~mm}$. It is important to emphasize that the presence of water, up to a certain extent, promoted the formation of agglomerates and in- creased the amount of surface defilements and, therefore, a relevant amount of small particle sized material (mainly $<1 \mathrm{~mm}$ ) was retained in bigger particle size ranges when the fine fractions were in raw state (i.e. in the presence of moisture).

\subsection{PSD analysis}

The PSD analysis determines the amount of material in a certain particle size/particle size range with respect to the total amount of material. Among bulk density and water content, PSD is of critical importance for the design of an adequate processing approach of the fine fractions, as it gives information about the distribution of the material throughput in particle size classification steps of the mechanical processing, which are required for an effective and efficient mechanical processing. Hence, the PSD of the fine fractions was determined for both raw and dry states, in which four composite samples $(n=4)$ from each batch were analyzed for each state. The obtained data from all batches was studied as a whole to produce and analyze the overall PSD curves of the fine fractions in both raw and dry states. This information is presented (Figure 9) using the 25th, 50th and 75th percentiles in order to show the median and variation range of the PSD, as well as to allow direct comparison between both states.

As displayed in Figure 9, the material in dry state presented a more uniform PSD than in raw state, since, as already mentioned, in moist conditions (raw state) fine particles, mostly $<1 \mathrm{~mm}$, tend to form agglomerates and adhere to coarser particles as surface defilements. Taking the curve for dry state as a reference for the real PSD of the fine fractions, it can be said that water content substantially influences the PSD of the material in a direct way and,

\section{- - - - "Water content (median)" —— "Water distribution (median)" —— "Dry mass distribution (median)"}

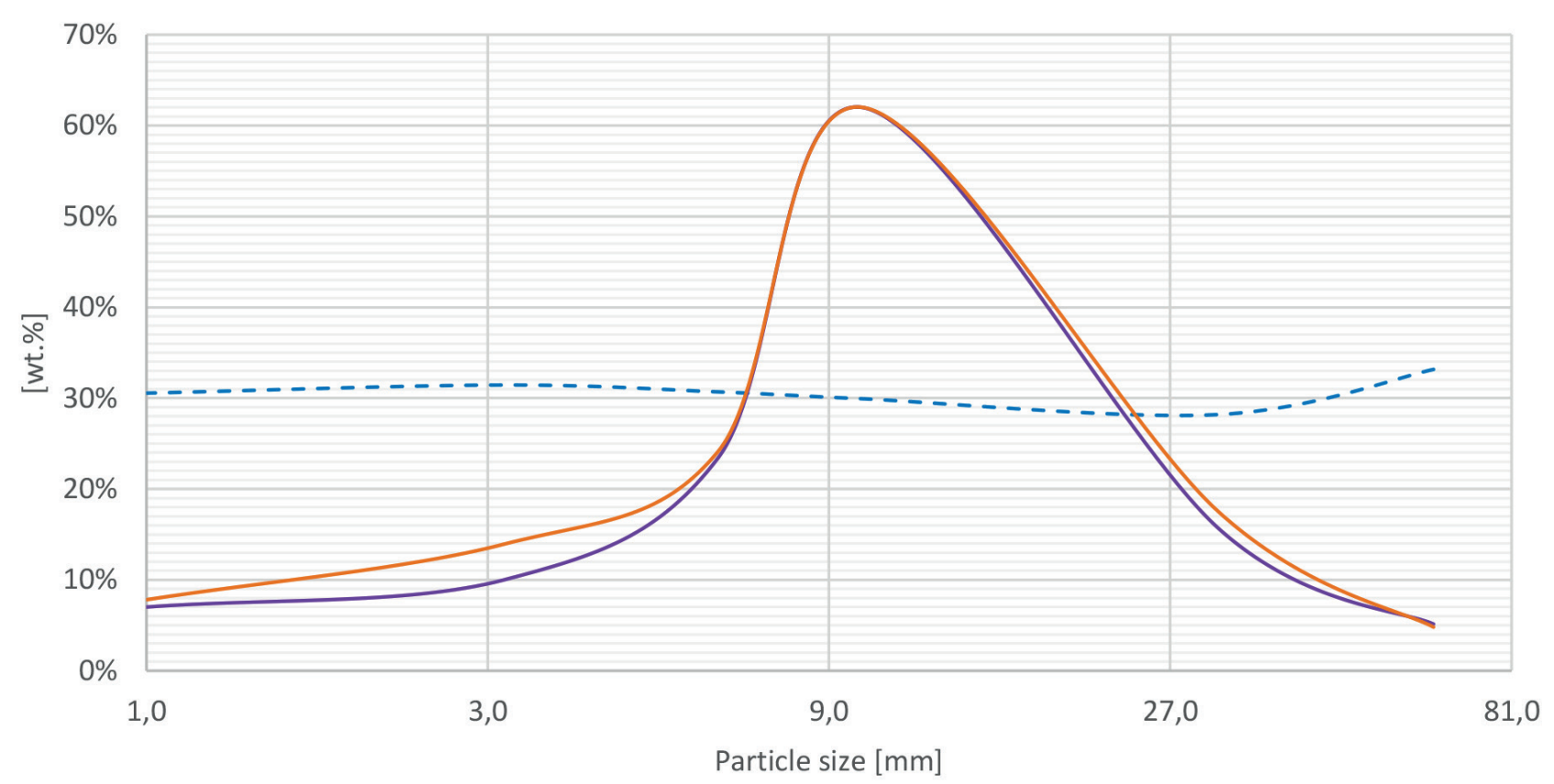

FIGURE 8: Water content, water and dry mass distribution in the fine fractions. 


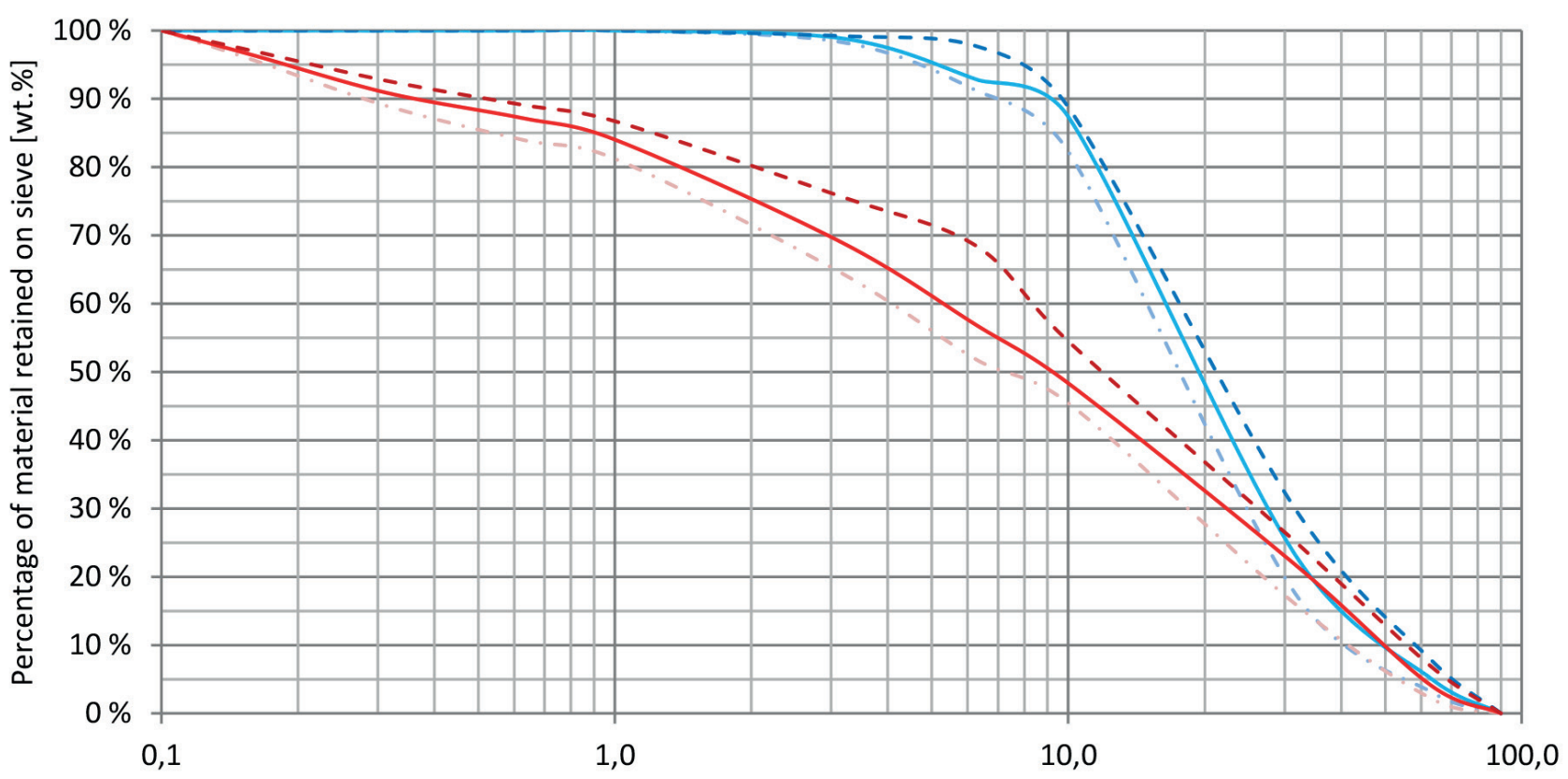

Sieve size $[\mathrm{mm}]$

FIGURE 9: PSD of the fine fractions in raw (blue) and dry (red) states.

thus, the performance of sieving steps throughout the mechanical processing as well.

Moreover, about $80-90 \mathrm{wt}$.\% of the fine fractions in raw state and around $45-55 \mathrm{wt} . \%$ in dry state were retained on the $10 \mathrm{~mm}$ sieve. On the contrary, fine fractions presented slighter differences between raw and dry states, regarding sieving performance, on the $31.5 \mathrm{~mm}$ sieve, in which 18-30 wt. $\%$ was retained in raw state and $16-25$ wt. $\%$ in dry state. Therefore, it can be concluded that the PSD analysis of the fine fractions in raw and dry states can be useful to identify the required number and optimal cut-off diameter size of the sieving steps of the mechanical processing. Additionally, the PSD analysis can be used to identify the optimal moisture content to process the fine fractions in a dry mechanical processing in order to minimize dust generation and material loss, while maintaining a high sieving efficiency and without the need of complete drying. Besides, the PSD analysis can be employed to pinpoint the particle size from which the material might require a drying step or wet processing.

For example, in this case an initial sieving down to around $30 \mathrm{~mm}$ could be performed to the fine fractions directly after the ballistic separation process, without the necessity of any drying step. Nevertheless, the impact of processing the excavated material in raw state on the quality (amount of impurities and surface defilements) of the fractions to be subsequently recovered from both coarse and fine fractions needs to be taken into account for this as well. Subsequently, the moisture content of the material $<30 \mathrm{~mm}$ could be either reduced or increased, according to the succeeding mechanical processing method (i.e. dry or wet), before applying an additional sieving at about $10 \mathrm{~mm}$. The moisture adjustment would serve the purpose of increasing the sieving efficiency, reducing the amount of material agglomerates and surface defilements and, hence, improving the performance of the following mechanical processing.

\subsection{Material composition}

Besides bulk density, water content and PSD, the material composition of the fine fractions is of decisive relevance for the design of an appropriate mechanical processing approach, as well as for the selection of the WtM and WtE strategies to follow. The types of materials that could be recovered from the fine fractions are identified by the determination of the material composition and, in combination with PSD analysis, it provides information regarding the amount and location, in terms of particle size range, of the materials to be recovered, as well as information required for selecting an adequate processing method. Thus, the material compositions of batches 1,3 and 4 were determined in both raw and dry conditions from a total of four composite samples $(n=4)$ for each batch and state. Photographs of the material types that constitute the grouped material fractions (i.e. "Combustibles", "Inert", "Total metals", "Others" and "Agglomerated fines < $10 \mathrm{~mm}$ ") defined in Section 2.3 are displayed in Figure 10. Due to strong similarities between batches 1 and 2 regarding visual material composition, bulk density, water content and PSD, the composition of batch 1 has been assumed valid for batch 2 as well. The composite samples of batch 2 were used to obtain additional information, such as the variation of bulk 
density and water content according to particle size, which modified the initial conditions of the material and, thus, did not allow obtaining reliable results if manual sorting were to be performed a posteriori. The data obtained from the material characterization of batches 1,3 and 4 was, hence, used to calculate the median material composition of the fine fractions as a whole.

In order to allow direct comparison between the results
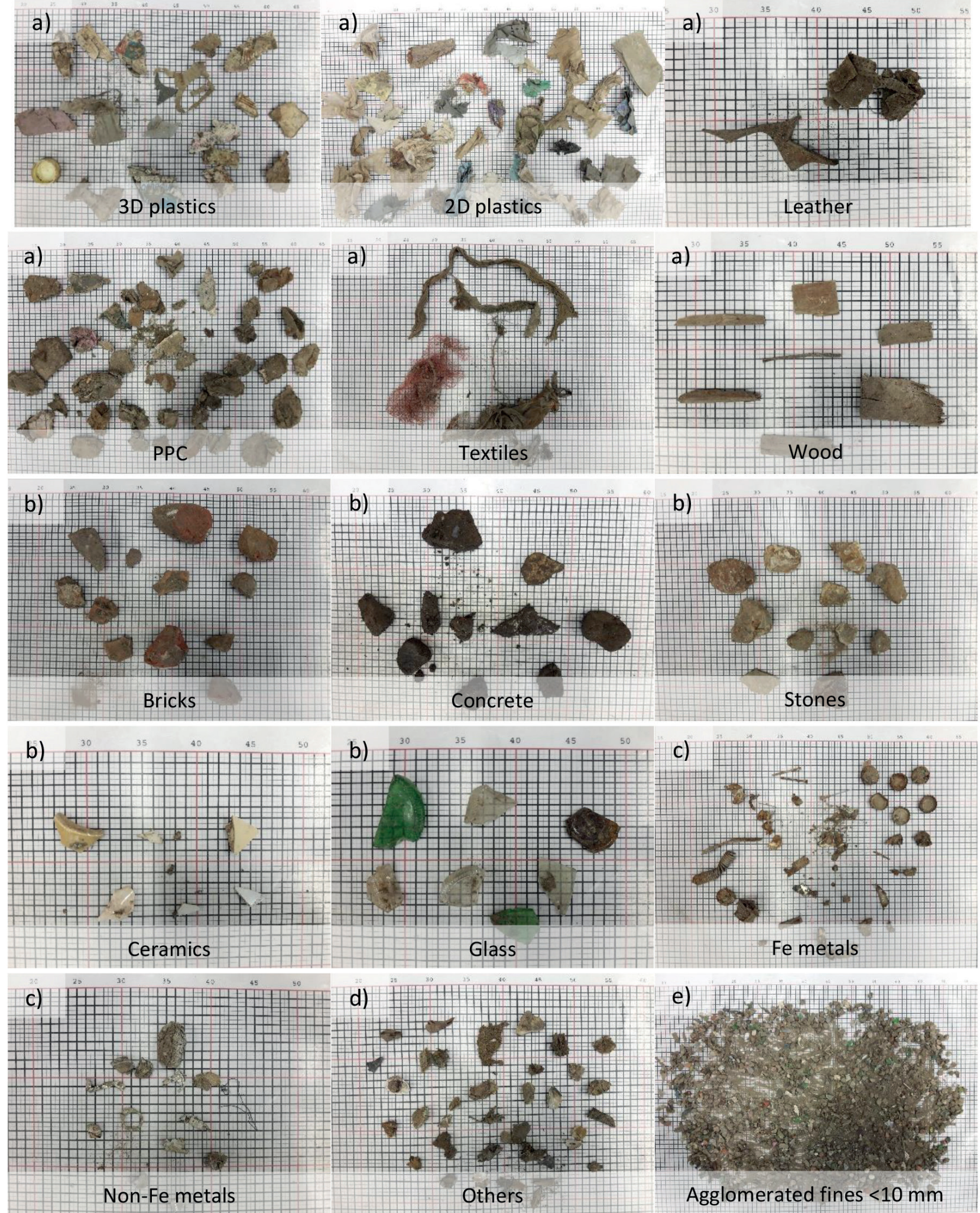

FIGURE 10: Photographs of the grouped material fractions: a) "Combustibles", b) "Inert", c) "Total metals", d) "Others" and e) "Agglomerated fines $<10 \mathrm{~mm}$. 
of raw and dry states, the water content of each material type was determined and deducted from the results of the material composition in raw state (i.e. raw state in water-free conditions). In this way, the capacity of some materials to absorb and adsorb water does not play a role in the results of weight distribution, which could lead to relevant misinterpretations in some cases.

The results of the material composition, classified in five grouped material fractions (i.e. "Combustibles", "Inert", "Total metals", "Others" and "Agglomerated fines < 10 $\mathrm{mm}$ ") and according to the three particle size ranges (i.e. 90-63 mm, 63-31.5 mm and 31.5-10 mm), for raw, raw (water-free) and dry states are presented in Table 3 . The material composition of the "Fine fractions $<10 \mathrm{~mm}$ " was not determined in this study and, thus, this fraction was included in Table 3 as "Mixed materials". It was visually detected that the fine fractions $<3.15 \mathrm{~mm}$ in both states mostly corresponded to a relatively homogeneous soil-like material, which in turn was mainly composed of weathered inorganic and degraded organic matter. The presence of "Combustibles", "Total metals" and "Others" could not be identified below $3.15 \mathrm{~mm}$.

The overall material composition of the fine fractions showed amounts of "Agglomerated fines $<10 \mathrm{~mm}$ " of about $1.1 \mathrm{wt} . \%$ and $1.1 \mathrm{wt} . \%$ in the particle size range $90-63 \mathrm{~mm}$, $1.7 \mathrm{wt} . \%$ and $1.5 \mathrm{wt} . \%$ in $63-31.5 \mathrm{~mm}$ and $35.4 \mathrm{wt} . \%$ and $34.2 \mathrm{wt} . \%$ in 31.5-10 mm in raw and raw (water-free) states, respectively. The amounts of the same fraction in dry state were around $0.1 \mathrm{wt} . \%$ in the particle size range $90-63 \mathrm{~mm}$,
0.2 wt.\% in 63-31.5 mm and 3.5 wt.\% in 31.5-10 mm, which means that the amount of agglomerated material is roughly ten times lower in dry state than in raw and raw (water-free) states. In turn, "Fine fractions $<10 \mathrm{~mm}$ (Mixed materials)" presented an amount of about 12.3 wt.\% and 11.8 wt.\% in raw and raw (water-free) states, respectively, versus around 51.8 wt.\% in dry state. This information confirms that a significant amount of "Fine fractions $<10 \mathrm{~mm}$ " tends to form agglomerates and adhere to bigger particles in raw state (presence of moisture), which end up mixed with and adhered to coarser material fractions (i.e. "Combustibles", "Inert", "Total metals" and "Others"), potentially leading to a reduction in efficiency and performance along the mechanical processing. For instance, the variation of the amounts of "Total metals" between raw, raw (water-free) and dry states are likely to be mainly attributed to the presence of surface defilements, which still remained attached to that fraction after drying in most of the samples.

The presence of surface defilements was visually identified in the "Combustibles", "Inert", "Total metals" and "Others" fractions in raw, raw (water-free) and dry states. As it can be logically expected, the amount of surface defilements was considerably larger in raw and raw (water-free) states than in dry state. It is important to point out that the material composition to be taken as a reference in (E)LFM projects and investigations regarding material and energy recovery is the one determined in dry state, since in this state the material composition is least influenced by the presence of water, agglomerates and surface defilements

TABLE 3: Material composition of the fine fractions per particle size range in raw, raw (water-free) and dry states.

\begin{tabular}{|c|c|c|c|c|c|c|c|c|c|c|}
\hline \multirow{3}{*}{\multicolumn{2}{|c|}{$\begin{array}{l}\text { Particle size range / } \\
\text { Grouped material fraction }\end{array}$}} & \multicolumn{9}{|c|}{ Amount [wt.\%] } \\
\hline & & \multicolumn{3}{|c|}{ Raw state } & \multicolumn{3}{|c|}{ Raw state (water-free) } & \multicolumn{3}{|c|}{ Dry state } \\
\hline & & $\begin{array}{c}\text { 25th } \\
\text { percentile }\end{array}$ & Median & $\begin{array}{c}\text { 75th } \\
\text { percentile }\end{array}$ & $\begin{array}{c}\text { 25th } \\
\text { percentile }\end{array}$ & Median & $\begin{array}{c}\text { 75th } \\
\text { percentile }\end{array}$ & $\begin{array}{c}\text { 25th } \\
\text { percentile }\end{array}$ & Median & $\begin{array}{c}\text { 75th } \\
\text { percentile }\end{array}$ \\
\hline \multirow{5}{*}{$\begin{array}{l}90-63 \\
\mathrm{~mm}\end{array}$} & Combustibles & 0.6 & 1.1 & 3.6 & 0.5 & 0.9 & 3.2 & 0.3 & 1.0 & 3.0 \\
\hline & Inert & 0.1 & 1.4 & 2.2 & 0.2 & 1.6 & 2.5 & 0.9 & 1.5 & 2.9 \\
\hline & Total metals & 0.0 & 0.0 & 0.2 & 0.0 & 0.0 & 0.2 & 0.0 & 0.0 & 0.2 \\
\hline & Others & 0.0 & 0.0 & 0.0 & 0.0 & 0.0 & 0.0 & 0.0 & 0.0 & 0.0 \\
\hline & $\begin{array}{l}\text { Agglomerated } \\
\text { fines }<10 \mathrm{~mm}\end{array}$ & 0.4 & 1.1 & 1.9 & 0.4 & 1.1 & 1.7 & 0.0 & 0.1 & 0.1 \\
\hline \multirow{5}{*}{$\begin{array}{l}63-31.5 \\
\mathrm{~mm}\end{array}$} & Combustibles & 2.4 & 5.9 & 8.0 & 1.9 & 4.7 & 5.9 & 0.7 & 2.7 & 6.4 \\
\hline & Inert & 5.6 & 7.6 & 8.0 & 7.2 & 8.5 & 9.9 & 8.7 & 9.7 & 13.2 \\
\hline & Total metals & 0.0 & 0.4 & 0.7 & 0.0 & 0.4 & 0.9 & 0.2 & 0.7 & 0.9 \\
\hline & Others & 0.1 & 0.3 & 0.8 & 0.1 & 0.4 & 0.8 & 0.0 & 0.2 & 1.6 \\
\hline & $\begin{array}{l}\text { Agglomerated } \\
\text { fines }<10 \mathrm{~mm}\end{array}$ & 0.6 & 1.7 & 9.7 & 0.6 & 1.5 & 9.0 & 0.2 & 0.2 & 0.3 \\
\hline \multirow{5}{*}{$\begin{array}{l}31.5-10 \\
\mathrm{~mm}\end{array}$} & Combustibles & 2.9 & 3.7 & 12.4 & 2.5 & 3.2 & 9.4 & 1.3 & 3.7 & 9.6 \\
\hline & Inert & 9.4 & 12.3 & 20.4 & 13.2 & 16.8 & 21.7 & 17.8 & 19.9 & 22.2 \\
\hline & Total metals & 0.3 & 0.4 & 0.6 & 0.4 & 0.6 & 0.7 & 0.3 & 0.5 & 0.7 \\
\hline & Others & 0.6 & 0.8 & 5.4 & 0.6 & 0.8 & 5.8 & 0.4 & 0.6 & 1.1 \\
\hline & $\begin{array}{l}\text { Agglomerated } \\
\text { fines }<10 \mathrm{~mm}\end{array}$ & 25.5 & 35.4 & 42.0 & 23.9 & 34.2 & 41.0 & 2.9 & 3.5 & 3.8 \\
\hline $\begin{array}{l}\text { Fine } \\
\text { fractions } \\
<10 \mathrm{~mm}\end{array}$ & Mixed materials & 11.3 & 12.3 & 15.3 & 11.1 & 11.8 & 14.6 & 37.8 & 51.8 & 55.6 \\
\hline
\end{tabular}


and, hence, reflects the material composition which is closest to reality. Therefore, discrepancies from the material composition in raw state with respect to the one in dry state can be explained by the presence of impurities and moisture. The latter being valid only if the quantities have not been calculated under water-free conditions. Nevertheless, more precise results of material composition might be achieved by implementing a washing step or wet sieving before the manual characterization, which will most likely require additional effort and time. The determination of the material composition in raw and raw (water-free) states is useful for the quantification and localization of material agglomerates and impurities, which are of critical relevance for the design of the mechanical processing.

In the case of the "Inert" fractions, amounts of about $1.4 \mathrm{wt} . \%$ and $1.6 \mathrm{wt} . \%$ in the particle size range $90-63 \mathrm{~mm}$, $7.6 \mathrm{wt} . \%$ and $8.5 \mathrm{wt} . \%$ in $63-31.5 \mathrm{~mm}$ and $12.3 \mathrm{wt} . \%$ and $16.8 \mathrm{wt} . \%$ in $31.5-10 \mathrm{~mm}$ were determined in raw and raw (water-free) states, while amounts of $1.5 \mathrm{wt} \%$, 9.7 wt.\% and 19.9 wt.\%, respectively, were obtained in dry state. These figures show that most of the "Inert" fraction was found between $31.5 \mathrm{~mm}$ and $10 \mathrm{~mm}$ in all three states and that the amount of "Inert" increased with the decrease in particle size. Nonetheless, the influence of moisture (agglomerates and surface defilements) might lead to misinterpretations if not taken into account properly, considering that the real amount of "Inert" is higher than the one shown by the compositions in raw and raw (water-free) states.

The amounts of "Combustibles" and "Others" showed inconsistent fluctuations between the different states and particle size ranges, which might be explained due to the fact that both correspond to the most heterogeneous grouped fractions and are composed of various materials with different properties.

The previous outcomes show that "Total metals" were less affected, in terms of impurities, by the presence of moisture and, therefore, they could be recovered in raw state of the fine fractions, provided that the original water content allows an effective particle size classification (sieving) a priori. On the other hand, other fractions, such as "Combustibles" and "Inert" fractions, might need either partial/complete drying or washing step before material recovery can be implemented efficiently.

In general, these results show that most of the amount of the grouped fractions is located between $63 \mathrm{~mm}$ and $10 \mathrm{~mm}$ and, therefore, omitting the sieving step at $63 \mathrm{~mm}$ and sieving directly at around $30 \mathrm{~mm}$ would be advisable for full scale processing of the fine fractions. Particle size classification, as well as most mechanical processing steps in (E)LFM, performs best with narrow differences in particle sizes, so a direct sieving from $90 \mathrm{~mm}$ to $10 \mathrm{~mm}$ would most likely lead to sieve clogging and bad performance of the equipment along the subsequent mechanical processing.

\subsection{Potential for material and energy recovery}

The findings presented above document the presence of materials in the fine fractions that could have potential for WtM and WtE (i.e. "Combustibles", "Inert" and "Total metals"), as well as the most important characteristics of the fine fractions (i.e. bulk density, water content and PSD) that are to be taken into account for the design of an effective and efficient mechanical processing. Provided that such mechanical processing is implemented, the fine fractions from the excavated area at MSG landfill could yield medians of about 8.0 wt.\% "Combustibles", 32.4 wt.\% "Inert", 1.3 wt.\% "Total metals", 0.9 wt.\% "Others", 3.8 wt.\% "Agglomerated fines $<10 \mathrm{~mm}$ " and $51.8 \mathrm{wt}$.\% "Fine fractions $<10 \mathrm{~mm}$ " (Table 4). As the fraction "Others" was mostly composed of organic matter (e.g. bones, shells, sponges, among others), which could be valorized thermally together with the "Combustibles" fraction, the total amount of combustibles could be slightly increased.

If processed in dry or reduced moisture state (optimal water content) most of "Agglomerated fines $<10 \mathrm{~mm}$ " would most likely end up in the "Fine fractions $<10 \mathrm{~mm}$ ", raising the amount of the latter as well. This fraction could be processed further in order to recover additional amounts of "Combustibles", "Inert" and "Total metals", since it was identified through PSD analysis and manual characterization that some of those material fractions were still present above $3.15 \mathrm{~mm}$. These additional amounts are most likely to be low; nonetheless, this is a necessary step in order to reduce the amount of undesired materials if the production of a soil substitute material is envisaged. As proposed in Hernández Parrodi et al., 2018b, "Fine fractions <10 mm" could be processed further to produce a material that can be used as soil substitute in construction applications, whereas the "Inert" fraction could be used for the production of construction aggregates and "Total metals" could be sent to recycling, following the WtM pathway. In turn, "Combustibles" (together with "Others") could be suitable to produce refuse derived fuel (RDF) and, thus, incorporate to a WtE scheme. Nonetheless, the mechanical processing approach is to be designed in such a way that the applicable specifications for the usage of such materials in the intended purposes are met as well.

It is relevant to note that the previous amounts were taken directly from the results of the manual characterization and PSD analysis without considering efficiencies of mechanical processing and material losses. Therefore, these figures may vary considerably in full scale processing.

TABLE 4: Material composition of the fine fractions in dry state.

\begin{tabular}{|c|c|c|c|c|}
\hline \multirow{2}{*}{\multicolumn{2}{|c|}{$\begin{array}{l}\text { Particle size range / } \\
\text { Grouped material fraction }\end{array}$}} & \multicolumn{3}{|c|}{ Amount [wt.\%] } \\
\hline & & \multirow{2}{*}{$\begin{array}{c}\begin{array}{c}\text { 25th } \\
\text { percentile }\end{array} \\
2.1\end{array}$} & \multirow{2}{*}{$\begin{array}{c}\text { Median } \\
8.0\end{array}$} & \multirow{2}{*}{$\begin{array}{c}\begin{array}{c}\text { 75th } \\
\text { percentile }\end{array} \\
19.7\end{array}$} \\
\hline \multirow{5}{*}{$\begin{array}{l}\text { Fine fractions } \\
90-10 \mathrm{~mm}\end{array}$} & Combustibles & & & \\
\hline & Inert & 31.1 & 32.4 & 35.4 \\
\hline & Total metals & 0.6 & 1.3 & 1.8 \\
\hline & Others & 0.6 & 0.9 & 3.4 \\
\hline & $\begin{array}{l}\text { Agglomerated } \\
\text { fines }<10 \mathrm{~mm}\end{array}$ & 3.3 & 3.8 & 4.2 \\
\hline $\begin{array}{l}\text { Fine fractions } \\
<10 \mathrm{~mm}\end{array}$ & $\begin{array}{l}\text { Mixed } \\
\text { materials }\end{array}$ & 37.8 & 51.8 & 55.6 \\
\hline
\end{tabular}




\section{CONCLUSIONS}

The determination of the main characteristics of the fine fractions, such as bulk density, water content, PSD and material composition, is of utmost importance for the design of a successful mechanical treatment process, as well as for assessing the potential for material and energy recovery from fine fractions in (E)LFM projects. Bulk density, water content, PSD and material composition, as well as the correlations between them, are necessary information in order to be able to predict the behavior of fine fractions in a certain mechanical processing method. Furthermore, they turn out to be critical parameters to be taken into account for an appropriate selection of processing methods. Moreover, material composition serves as a basis to identify the strategies to follow regarding WtM and WtE in (E)LFM.

In this case study about 77 wt.\% of the total landfill-mined material in raw state corresponded to the fine fractions (material $<90 \mathrm{~mm}$ ), which had an overall bulk density range of $720-1000 \mathrm{~kg} / \mathrm{m}^{3}$ and a total water content range of 25-30 wt.\%. In general, bulk density appeared to increase as particle size decreased in both raw and dry states. Nevertheless, a decrease in bulk density was observed in the particle size range $<0.16 \mathrm{~mm}$ in dry state. Furthermore, the overall bulk density was reduced about 21 wt.\% after drying the fine fractions, which can be very useful information for the design of the mechanical processing.

The amount of moisture contained in the fine fractions substantially influences the presence of "Agglomerated fines $<10 \mathrm{~mm}$ ", as well as the amount of impurities in the fractions "Combustibles", "Inert", "Total metals" and "Others". "Total metals" seemed to be less influenced by water content and, therefore, their recovery could be done in raw state, given that the original water content allows an adequate particle size classification a priori. For the recovery of the "Combustibles", "Inert" and "Others" fractions and further processing of the "Fine fractions $<10 \mathrm{~mm}$ ", additional drying/moisture reduction or washing step/wet processing might be required in order to achieve adequate mechanical processing and obtain acceptable material qualities.

In addition to the determination of the relative mass distribution according to size, the PSD analysis in both raw and dry states can be used to identify the particle size from which the fine fractions might require a drying step or wet processing. Moreover, such analysis can also be utilized to determine the optimal water content in order to minimize dust generation and material loss during dry mechanical processing without the need of complete drying.

Results on the material composition in dry state reveal that amounts of 2.1-19.7 wt.\% "Combustibles", 31.1-35.4 wt.\% "Inert" and 0.6-1.8 wt.\% "Total metals" could be recovered from the fine fractions $90-10 \mathrm{~mm}$, while 37.8-55.6 wt.\% "Fine fractions $<10 \mathrm{~mm}$ " could be processed further in order to increase the recovery amounts of the previous fractions and produce a substitute material for soil in construction applications. For this, applicable specifications for the usage of such materials in the foreseen purposes need to be taken into account.

It is highly important to highlight that the findings of this study are only valid for the investigated area at the landfill site and, therefore, additional studies covering the complete landfill area of the site are to be done in order to determine the overall material composition and characteristics of the MSG landfill, as well as to assess the global potential for WtM and WtE. Additionally, it is of critical relevance to point out that one of the greatest challenges faced by (E)LFM remains to be the processing of the fine fractions for the recovery of valorizable fractions in an economically feasible manner, since the implicated capital and operating expenditures continue to outweigh the revenues obtained by the valorization of those fractions. However, this situation is more related to policy and market aspects than to its technical feasibility.

\section{ACKNOWLEDGEMENTS}

This research has been funded by the European Union's Horizon 2020 research and innovation programme under the Marie Skłodowska-Curie grant agreement No. 721185 “NEW-MINE" (EU Training Network for Resource Recovery through Enhanced Landfill Mining; www.new-mine.eu). The authors wish to express their special gratitude to Renewi Belgium SA/NV, Stadler Anlagenbau GmbH and the Department of Processing and Recycling (IAR) of the RWTH Aachen University for their straightforward collaboration and support.

\section{REFERENCES}

Bhatnagar, A., Kaczala, F., Burlakovs, J., Kriipsalu, M., Hogland, M., Hogland, W., 2017. Hunting for valuables from landfills and assessing their market opportunities: A case study with Kudjape landfill in Estonia. Waste Management \& Research 17, 0734242X1769781. $10.1177 / 0734242 \times 17697816$.

Bureau d'études greisch, 2002. Centre d’Enfouissement Technique de Mont-Saint-Guibert: Etude des conséquences de l'octroi du permis d'urbanisme du 29.10.01 sur les conditions d'exploitation du permis du 16.12.98.

D’Or, D., 2013. Modélisation et caractérisation des émissions surfaciques de biogaz sur les C.E.T. en RW: Traitement des données de la champagne de mesures de septembre-octobre 2012 sur le CETeM. Ephesia Consult.

Gaël, D., Tanguy, R., Nicolas, M., Frédéric, N., 2017. Assessment of multiple geophysical techniques for the characterization of municipal waste deposit sites. Journal of Applied Geophysics 145, 74-83. 10.1016/j.jappgeo.2017.07.013.

García López, C., Ni, A., Hernández Parrodi, J.C., Küppers, B., Raulf, K., \& Pretz, T. (2019). Characterization of landfill mining material after ballistic separation to evaluate material and energy recovery potential. Detritus, 8(1), 5-23. https://doi.org/10.31025/26114135/2019.13780.

Hernández Parrodi, J.C., Höllen, D., Pomberger, R., 2018a. Characterization of fine fractions from landfill mining: A review of previous investigations. Detritus 2 (1), 46-62. 10.31025/26114135/2018.13663.

Hernández Parrodi, J.C., Höllen, D., Pomberger, R., 2018b. Potential and main technological challenges for material and energy recovery from fine fractions of landfill mining: A critical review. Detritus 3 (1), 19-29. https://doi.org/10.31025/2611-4135/2018.13689.

Hernández Parrodi, J.C., Lucas, H., Gigantino, M., Sauve, G., Esguerra, J.L., Einhäupl, P., et al. (2019). Integration of resource recovery into current waste management through (enhanced) landfill mining. Detritus, 8(1), 141-156. 10.31025/2611-4135/2019.13884

Hull, R.M., Krogmann, U., Strom, P.F., 2005. Composition and Characteristics of Excavated Materials from a New Jersey Landfill. J. Environ. Eng. 131 (3), 478-490. 10.1061/(ASCE)07339372(2005)131:3(478). 
IGRETEC, 1994. Centre d’Enfouissement Technique de Mont-SaintGuibert: Etudie des incidences sur l'environnement.

Jones, P.T., Geysen, D., Rossy, A., Bienge, K., 2010. Enhanced Landfill Mining (ELFM) and Enhanced Waste Management (EWM): essential components for the transition to Sustainable Materials Management (SMM). Proceedings of the 1st International Academic Symposium on Enhanced Landfill Mining. 4-6 October, 2010. Houthalen-Helchteren, Belgium.

Jones, P.T., Geysen, D., Tielemans, Y., van Passel, S., Pontikes, Y., Blanpain, B., Quaghebeur, M., Hoekstra, N., 2013. Enhanced Landfill Mining in view of multiple resource recovery: a critical review. Journal of Cleaner Production 55, 45-55. 10.1016/j.jclepro.2012.05.021.
Jones, P.T., Tielemans, Y., 2010. Enhanced Landfill Mining and the Transition to Sustainable Materials Management. Proceedings of the 1st International Academic Symposium on Enhanced Landfill Mining. 4-6 October, 2010. Houthalen-Helchteren, Belgium, 325.

Krook, J., Svensson, N., Eklund, M., 2012. Landfill mining: A critical review of two decades of research. Waste Management 32 (3), 513-520. 10.1016/j.wasman.2011.10.015.

Münnich, K., Fricke, K., Wanka, S., Zeiner, A., 2013. Landfill Mining: A contribution to conservation of natural resources? Proceedings Sardinia 2013. Fourteenth International Waste Management and Landfill Symposium. 30 Sep. - 4 Oct., 2013. S. M. di Pula, Cagliari, Italy. 